\title{
Fundamental Personal Rights: Another Approach to Equal Protection
}

The recent history of the United States Supreme Court is often said to be marked by a decisive turning point in the method and substance of constitutional adjudication. ${ }^{1}$ Between 1934 and 1937 the Court began to abandon most of the reasoning of and the policies embodied in "substantive due process," 2 and by 1941 the old doctrine was explicitly repudiated. ${ }^{3}$ The pre-1937 Court's approach to interpreting the vague provisions of the due process clauses may best be characterized as a "balancing" of the burdens imposed on a person's life, liberty or property by governmental regulation against the governmental justifications for the burdens. In many of these substantive due process cases, the Court found the regulation in question insufficiently justified and therefore unconstitutional. 4 In many other cases, however, the pre-1937 Cóurt found the regulation to be a reasonable exercise of governmental power. ${ }^{5}$

One of the primary objections to the substantive due process approach was that the Court substituted its judgment of the wisdom of legislation for that of the popularly elected branches of government. ${ }^{6}$ In response to this criticism, the post-1937 Court developed an approach

1 E.g., McCloskey, Economic Due Process and the Supreme Court: An Exhumation and Reburial, 1962 SuP. CT. REv. 34; Stern, The Problems of Yesteryear-Commerce and Due Process, 4 VAND. L. REv. 446 (1951).

2 See West Coast Hotel Co. v. Parrish, 300 U.S. 379 (1937); Nebbia v. New York, 291 U.S. 502 (1934).

3 Olsen v. Nebraska, 313 U.S. 236 (1941). See Ferguson v. Skrupa, 372 U.S. 726, 728-32 (1963).

4 E.g., New State Ice. Co. v. Liebmann, 285 U.S. 262 (1932); Pierce v. Society of Sisters, 268 U.S. 510 (1925); Meyer v. Nebraska, 262 U.S. 390 (1923); Adkins v. Children's Hosp., 261 U.S. 525 (1923); Adams v. Tanner, 244 U.S. 590 (1917); Coppage v. Kansas, 236 U.S. 1 (1915); Lockner v. New York, 198 U.S. 45 (1905); Allgeyer v. Louisiana, 165 U.S. 578 (1897). See generally Hamilton, The Path of Due Process of Law, 48 Ethics 269 (1938), in THE Constitution ReconstDered 167 (C. Read ed. 1968); Warren, The New "Liberty" Under the Fourteenth Amendment, 99 HARv. L. REv. 431 (1926).

5 E.g., Village of Euclid v. Ambler Realty Co., 272 U.S. 365 (1926); Bunting v. Oregon, 243 U.S. 426 (1917); New York Central R.R. v. White, 243 U.S. 188 (1917); Chicago, B. \& Q.R.R. v. McGuire, 219 U.S. 549 (1911); Muller v. Oregon, 208 U.S. 412 (1908); Holden v. Hardy, 169 U.S. 366 (1898).

6 E.g., AF of L v. American Sash \& Door Co., 335 U.S. 538, 542 (1949) (Frankfurter, J., concurring); L. BOUdIN, GOVERNMENT BY JubICIARY (1932); Lerner, Minority Rule and the Constitutional Tradition, in THE CONSTITUTION RECONSDERED 191 (C. Read ed. 1968). 
to the due process and equal protection clauses that applies "minimal judicial scrutiny," embodied in the "reasonable relationship" test, to most legislation and "strict judicial scrutiny," embodied in the "compelling governmental interest" test, to legislation that impinges upon some of the rights protected by the Bill of Rights or upon certain political rights, or discriminates against "discrete and insular minorities." In protecting members of minority groups the Court has held that certain legislative classifications, such as those based on race, are "suspect" and therefore require extraordinary justifications.

Two difficulties bedevil the "suspect classification" approach. As the Court expands the list of suspect characteristics to include nationality, alienage, illegitimacy, and possibly sex, it opens itself to the charge that its choice of which "discrete and insular minorities" to protect is arbitrary given the large number of such groups in our society. ${ }^{8}$ Second, the suspect classification approach almost always results in a finding of unconstitutionality of the legislation in question. ${ }^{9}$ Since the minimal judicial scrutiny applied to most legislation almost always results in the opposite finding, the Court appears to be boxed in by a rigid twotier system in which the conclusion is almost automatic once the Court decides whether a classification is suspect or not. ${ }^{10}$

In practice, however, the different judicial findings that appear to be the automatic result of which verbal formula is applied are better explained as different judicial evaluations of the nature of the interests in question, the magnitude of the burdens imposed on affected individuals, and the sufficiency of the government's justification for imposing the burdens. ${ }^{11}$ Recognition of this fact appears to have encouraged some members of the Court who wish to avoid the rigidity of the two-tier approach to develop an intermediate level of judicial scrutiny that may be embodied in the "substantial relationship in fact" test. ${ }^{12}$ This

7 This approach was first articulated in United States v. Carolene Prods., 304 U.S. 144, 152-53 \& n.4 (1938) (plurality opinion) (dictum).

8 E.g., In re Griffiths, 93 S. Ct. 2851, 2861 (1973) (Rehnquist, J., dissenting). See text and notes at notes $47-49$ infra.

9 See text and notes at notes 28-33 infra.

10 See text and notes at notes 15-27 \& 50 infra. The Court's fundamental rights approach often appears to share this rigidity. A few recent cases, however, indicate that the Court is adopting a more flexible approach to fundamental rights. See text and notes at notes 105-115 infra.

11 See, e.g., Developments in the Law-Equal Protection, 82 HARv. L. REv. 1065 (1969); Comment, The Evolution of Equal Protection-Education, Municipal Services, and Wealth, 7 HARv. Civ. Righrs-Civ. Lib. L. Rev. 103 (1972).

12 See Vlandis v. Kline, 93 S. Ct. 2230, 2238 (1973) (White, J., concurring); San Antonio Independent School Dist. v. Rodriguez, 93 S. Ct. 1278, 1315 (1973) (Marshall \& Douglas, J.J., dissenting); Gunther, Foreword: In Search of Evolving Doctrine on a Changing Court: A Model for a Newer Equal Protection, 86 Harv. L. Rev. 1 (1972). 
approach is not yet firmly established in the Court's opinions, but lower court applications of this "intermediate scrutiny" appear to be just as arbitrary as the strict scrutiny approach because no court has yet developed principled standards for determining whether a legislative classification is substantially related in fact to the legitimate goals of the law in question. ${ }^{13}$

Another branch of the strict scrutiny approach, "fundamental personal rights," has blossomed in recent equal protection cases.14 The fundamental personal rights approach, although now almost as rigid as the suspect classification approach, can easily be developed so as to provide a framework for more acceptable, more flexible and yet also more principled decisions.

This comment examines the minimal judicial scrutiny embodied in the reasonable relationship test, the strict judicial scrutiny embodied in the suspect classification test, and the intermediate scrutiny embodied in the substantial relationship in fact test and concludes that, in their present form, they are largely unsatisfactory as approaches to constitutional adjudication. The comment then examines the strict judicial scrutiny presently embodied in the fundamental rights approach and concludes that with minor modifications this approach is a more promising one for interpreting and applying the vague provisions of the equal protection clause.

\section{Three Approaches to Equal Protection}

The traditional view of the equal protection clause is that it requires a legislative or administrative classification to include all and only those persons similarly situated with respect to the law or regulation's legitimate governmental purpose. ${ }^{15}$ Very few classifications are precise enough to meet this test in practice, however, and the Court has developed various formulas to indicate the permissible degrees of underor overinclusiveness. ${ }^{16}$

\footnotetext{
13 See text and notes at notes 58-81 infra.

14 See text and notes at notes 82-115 infra.

15 See Tussman and tenBroek, The Equal Protection of the Laws, 37 GaLIF. L. REv. 341 (1949).

16 E.g., "[T]he classification must be reasonable, not arbitrary, and must rest upon some ground of difference having a fair and substantial relation to the object of the legislation, so that all persons similarly circumstanced shall be treated alike." F.S. Royster Guano Co. v. Virginia, 253 U.S. 412, 415 (1920). An "underinclusive" classification is one that does not include all those who are similarly situated with respect to the governmental goals sought to be attained by the classification, an "overinclusive" classification includes more than just those who are similarly situated.
} 
A. Reasonable Relationship to Legitimate Ends

In most cases a classification is deemed permissible if it is found to have a "reasonable relationship" to a legitimate governmental interest.17 A leading example of this approach is McGowan $v$. Maryland. ${ }^{18}$ In $M c$ Gowan, employees of a large discount store were convicted of violating Maryland's "Sunday Closing Law" by selling merchandise that was not exempted from the ban on Sunday sales. The employees argued that the law's exemption of "tobacco products, confectioneries, milk, bread, fruits, gasoline, oils, greases, drugs and medicines, and newspapers and periodicals"10 unreasonably discriminated against sellers of other goods.

The Court held that "State legislatures are presumed to have acted within their constitutional power despite the fact that, in practice, their laws result in some inequality. A statutory discrimination will not be set aside if any state of facts reasonably may be conceived to justify it."20 The Court then found that although the law favored some retail employees and disfavored others, a legislature could reasonably have determined that "the Sunday sale of the exempted commodities was necessary either for the health of the populace or for the enhancement of the recreational atmosphere of the day."21 By holding that this type of hypothetical justification was sufficient, the post-1937 Court effectively abandoned judicial review of most legislation. ${ }^{22}$

$M c$ Gowan and similar recent cases ${ }^{23}$ represent a continuation of the "Roosevelt Court's" approach to equal protection. In Kotch v. Board of River Port Pilot Commissioners, ${ }^{24}$ for example, the Court held that Louisiana's administrative exclusion from the river pilot profession of all but relatives and friends of current pilots was constitutional. The Court hypothesized that Louisiana's method of pilot selection might

17 E.g., San Antonio Independent School Dist. v. Rodriguez, 93 S. Ct. 1278 (1973); McDonald v. Board of Election Comm'rs, 394 U.S. 802 (1969); Williamson v. Lee Optical Co., 348 U.S. 483 (1955); Railway Express Agency v. New York, 336 U.S. 106 (1949); Lindsley v. Natural Carbonic Gas Co., 220 U.S. 61 (1911).

18366 U.S. 420 (1961).

19 Id. at $422-23$.

20 Id. at $425-26$ (citations omitted).

21 Id. at 426.

22 See Schrock, The Liberal Court, the Conservative Court, and Constitutional Jurisprudence, in LefT, RIGHT AND CENTER: EsSAYS ON Liberalism AND CONSERVATISM IN THE UNITED STATES 87 (R. Goldwin ed. 1967); McCloskey, supra note 1.

23 E.g., McGinnis v. Royster, 93 S. Ct. 1055 (1973); Lehnhausen v. Lake Shore Auto Parts Co., 93 S. Ct. 1001 (1973); United States v. Kras, 409 U.S. 434 (1973); Jefferson v. Hackney, 406 U.S. 535 (1972); James v. Valtierra, 402 U.S. 137 (1971); Dandridge v. Williams, 397 U.S. 471 (1970).

24330 U.S. 552 (1947). 
have increased "congeniality" among pilots and thus was rationally related to the legitimate goal of securing "the safest and most efficiently operated pilotage system practicable."25

The post-1937 Court's tolerance for under- and overinclusive classifications under the reasonable relationship test was so great that between 1937 and 1970 only one state law was found to be unreasonable and to violate the equal protection clause. In that case, Morey $v$. Doud, ${ }^{26}$ the Court held that the statutory exemption by name of the American Express Company from regulation under the Illinois Community Currency Exchanges Act was unconstitutional. Illinois argued that the unquestioned solvency and high financial standing of the American Express Company was a reasonable basis for the exemption, but the Court hypothesized that since the purpose of the Act should be the continued protection of the public, and since American Express might become a less reliable company in the future, the challenged classification was unreasonable.

As these examples indicate, the Court's use of hypotheses in reasonable relationship cases can lead to opposite results in similar cases. In Morey, the Court ignored an actual reasonable relationship to an actual legitimate end, reinterpreted the purpose of the Illinois Act, and hypothesized that under a possible future set of facts the classification would not be reasonably related to the Court's interpretation of the legislative purpose. In almost all other cases, however, the Court has held that hypothetical legitimate governmental ends and states of facts provide sufficiently reasonable relationships between the challenged classifications and the Court-defined legitimate purposes. The minimal judicial scrutiny embodied in the reasonable relationship approach to equal protection has therefore almost always resulted in a finding of constitutionality based on judicial deference to the expertise and political power of the legislative and executive branches of government. 27

25 Id. at 564.

26354 U.S. 457 (1957).

27 A few recent cases purportedly employing the reasonable relationship approach have found legislation to be prohibited by the equal protection clause. See text and notes at notes 58-81 infra. Moreover, the post-1937 Court has employed a reasonable relationship approach to other provisions of the Constitution and found legislation to be unreasonable. In Toomer v. Witsell, 384 U.S. 410 (1948), for example, the Court found a law that discriminated against out-of-state fishermen unconstitutional not because it lacked the "reasonable relationship" required by equal protection clause, but because it lacked the reasonable relationship required by the privileges and immunities clause of Article IV, section 2. The Court's reluctance to find the law unconstitutional under the reasonable relationship approach to the equal protection clause appears all the more surprising in view of the twisting of prior privileges and immunities cases that was required to justify 


\section{B. Suspect Classifications}

In a few pre-1937 cases the Court held that the equal protection clause prohibited state legislation that discriminated on the basis of race. ${ }^{28}$ The post-1937 Court extended this aspect of the equal protection clause by developing a strict scrutiny approach for laws that employed a "suspect" classification.

In Korematsu $v$. United States" the Court noted that "all legal restrictions which curtail the civil rights of a single racial group are immediately suspect. That is not to say that all such restrictions are unconstitutional. It is to say that the courts must subject them to the most rigid scrutiny."30

The Court's strict judicial scrutiny of suspect classifications was eventually embodied in the "necessary to a compelling governmental interest" test. ${ }^{31}$ No laws, except those challenged in Korematsu, have ever passed this test. For all practical purposes, therefore, any law employing a suspect classification is unconstitutional. ${ }^{32}$ The justification for the Court's strict scrutiny, at least according to the language of the opinions, is not a possible lack of legitimate ends, nor a possible denial

its opinion in Toomer. Cf. Kurland, The Privileges or Immunities Clause: "Its Hour Come Round at Last"?, 1972 WASH. U.L.Q. 405.

28 Nixon v. Condon, 286 U.S. 73 (1932); Nixon v. Herndon, 273 U.S. 536 (1927); Yick Wo v. Hopkins, 118 U.S. 356 (1886); Strauder v. West Virginia, 100 U.S. 303 (1880); cf. Buchanan v. Warley, 245 U.S. 60 (1917) (due process clause forbids racial restrictions on the right to sell real property).

29323 U.S. 214 (1944).

30 Id. at 216. In Korematsu the Court held that "[p]ressing public necessity" justified the relocation of all persons of Japanese descent, both American citizens and aliens, from the West Coast to detention camps during the Second World War. Id. The law was held justified even though the classification was grossly under- and overinclusive (citizens and aliens of German and Italian ancestry were not excluded from any part of the United States; none of the 70,000 affected citizens proved to be disloyal). See M. Grodzins, Amerrcans Betrayed: Polrtics and the JapAnese Evaguation (1949); Rostow, The Japanese American Cases-A Disaster, 54 YALE L.J. 489 (1945).

31 See In re Griffiths, 93 S. Ct. 2851, 2855 n.9 (1973); Graham v. Richardson, 403 U.S. 365, 375-76 (1971). See also Funter v. Exickson, 393 U.S. 385, 392 (1969); Loving v. Virginia, 388 U.S. 1, 11 (1967); McLaughlin v. Florida, 379 U.S. 184, 192 (1964).

32 Recent lower court cases suggest that the use. of suspect classifications to confer a justified benefit on members of a minority group is constitutional. See Carter v. Gallagher, 452 F.2d 315 (8th Gir. 1971), cert. denied, 406 U.S. 950 (1972); Contractors' Ass'n v. Secretary of Labor, 442 F.2d 159 (3d Cir), cert. denied, 404 U.S. 854 (1971); DeFunis v. Odegaard, 82 Wash. 2d 11, 507 P.2d 1169 (1973); appeal filed, 42 U.S.L.W. 3080 (U.S. Aug. 3, 1973) (No. 73-235); $c \dot{f}$. Swann v. Charlotte-MecKlenburg Bd. of Educ., 402 U.S. 1 (1971). See generally O'Neil, Preferential Admissions: Equalizing the Access of Minority Groups to Higher Education, 80 YALE L.J. 669 (1971); Developments, supra note 11, at 1104-20; Comment, Alternative Schools for Minority Students: The Constitution, the Civil Rights Act and the Berkeley Experiment, 61 CAL. L. REv. 858 (1973). 
of an individual's rights, but the existence of a discriminatory group classification as a means to a presumably valid end. ${ }^{33}$

Given the leniency of the rational relation test and the strictness of the suspect classification test, the critical factor in a determination of the constitutionality of legislation becomes whether or not a particular group classification is suspect. Almost all jurists and commentators believe that the equal protection clause, at a minimum, requires strict judicial scrutiny of racial classifications. ${ }^{34}$ It is questionable, however, whether other classifications, such as those based on alienage, nationality, illegitimacy, or sex, should be considered suspect, and, more importantly, whether the suspect classification approach adequately protects individual rights.

In three recent cases, the Court has held that any classification based on alienage, regardless of racial considerations, is suspect. ${ }^{35}$ In these cases the court held that although the goals of the statutes were legitimate $^{36}$ the means chosen, complete or partial exclusion of aliens, were prohibited by the equal protection clause. The Court argued that aliens were archetypical of the "discrete and insular minorities"37 that the Fourteenth Amendment was designed to protect from the tyranny of legislative majorities.

The prime difficulty with the suspect classification approach is the lack of consistently applicable standards for choosing which minority groups to protect. For example, why aliens and not minors? Both groups

33 E.g., Sugarman v. Dougall, 93 S. Ct. 2842, 2847-51 (1973).

34. A notable exception is H. WECHSLER, Toward Neutral Principles of Constitutional Law, in Principles, Polmtics, and Fundamental Law xiii-xv, 3 (1961).

35 In re Griffiths, 93 S. Ct. 2851 (1973); Sugarman v. Dougall, 93 S. Ct. 2842 (1973); Graham v. Richardson, 403 U.S. 365 (1971).

36 In Griffiths, Connecticut sought to maintain sufficiently high qualifications for lawyers by completely excluding aliens from the Connecticut Bar. 93 S. Ct. at 2855-58. In Sugarman, New York sought, among other goals, to maintain a sufficient level of loyalty and knowledge among members of the competitive civil service by completely excluding aliens. $93 \mathrm{~S}$. Ct. at 2847-50. In Graham, Arizona sought to limit expenditures for welfare payments by imposing a fifteen-years-in-the-state residence requirement only on resident aliens, 403 U.S. at $372-76$.

37 All three cases quote and rely upon this phrase from United States v. Carolene Products, 304 U.S. 144, 152-53 n.4 (1938) (dictum), to justify strict judicial scrutiny. $93 \mathrm{~S}$. Ct. at 2854-55; 93 S. Ct. at 2847; 403 U.S. at 372. It is important to note that alienage, unlike race, nationality, and sex, is not an immutable characteristic except insofar as certain prerequisites for citizenship are imposed. Once the prerequisites are satisfied, the status of alien must be viewed as a voluntary status. Although in general the mutable status of alienage is linked with the immutable characteristic of nationality, finding alienage in general to be a suspect classification calls into serious question the "accident of birth" justification for finding a classification to be suspect. See text and notes at notes 40-46 infra. 
are similar insofar as most or all of their members can or will become members of the favored majority class, i.e., citizens or adults, respectively. Members of both groups are temporarily denied various important rights and privileges simply because of their status and regardless of their individual qualifications. From this point of view there appears to be little reason, except administrative convenience, why an individual minor should not be given the opportunity to rebut the presumption that he or she does not possess the necessary qualifications to contract, to drive, to marry, or to vote, for example. ${ }^{38}$ The minimum age requirements for these rights and privileges appear to be no better related to the goals of the statutes, e.g., insuring well-qualified drivers or voters, than the citizenship requirement was. $^{39}$

The Court has indicated that classifications based on nationality, ${ }^{40}$ illegitimacy, ${ }^{41}$ and sex ${ }^{42}$ may also be suspect. Three justification have been given for these additions to the list of suspect classifications. First, nationality, illegitimacy and sex generally are, like race, "immutable characteristic[s] determined solely by the accident of birth." 43 Second,

38 Cf. Vlandis v. Kline, 93 S. Ct. 2230 (1973). In Vlandis the Court held that Connecticut's irrebuttable presumption that state university students who were nonresidents at the time of application for admission continue to be nonresidents for tuition purposes while attending the university violates the due process clause. The dissenting opinion of the Chief Justice points out that the Court's approach in Vlandis is identical to the strict scrutiny approach developed in equal protection cases. Id. at 2240. Vlandis, Stanley v. Illinois, 405 U.S. 645 (1972); Eisenstádt v. Baird, 405 U.S. 438 (1972); Richardson v. Belcher, 404 U.S. 78 (1971); Boddie v. Connecticut, 401 U.S. 371 (1971); and Shapiro v. Thompson, 394 U.S. 618 (1969) indicate that equal protection cases could easily be decided by the Court under the due process clauses. For a discussion of the post-I937 Court's equal protection cases and their similarity to the "substantive due process" cases of the pre-1937 Court, see Karst, Invidious Discrimination: Justice Douglas and the Retum of the "Natural Law-Due Process Formula," 16 U.C.L.A.L. Rev. 716 (1969); Karst \& Horowitz, Reitman v. Mulkey: A Telophase of Substantive Equal Protection, 1967 SuP. Gr. REv. 39. See also, Michelman, Foreword: On Protecting the Poor Through the Fourteenth Amendment, 83 HARv. L. REv. 7 (1969). Since equal protection questions can be reformulated as due process questions, this comment's suggested approach to equal protection is also applicable to due process adjudication. See text and notes at notes 51-57 infra.

39 Cf. Dunn v. Blumstein, 405 U.S. 330, 363 (1972) (Burger, C.J., dissenting).

40 See Oyama v. California, 332 U.S. 633, $644-46$ (1948); Korematsu v. United States, 323 U.S. 214, 216 (1944); Hirabayashi v. United States, 320 U.S. 81, 100 (1943). These cases may also be viewed as racial discrimination or alienage cases.

41 See Gomez v. Perez, 409 U.S. 535 (1973); Weber v. Aetna Cas. \& Sur. Co., 406 U.S. 164 (1972); Levy v. Louisiana, 391 U.S. 68 (1968). But see Labine v. Vincent, 401 U.S. 532 (1971).

42 Cf. Frontiero v. Richardson, 93 S. Ct. 1764 (1973); Reed v. Reed, 404 U.S. 71 (1971); text and notes at notes 60-67 infra. But cf. Forbush v. Wallace, 341 F. Supp. 217 (M.D. Ala. 1971), aff'd mem., 405 U.S. 970 (1972).

43 Frontiero v. Richardson, 93 S. Ct. 1764, 1770 (1973) (plurality opinion). Illegitimacy, of course, is mutable if illegitimates can be legitimated after birth. In this respect it is more like alienage if aliens can become citizens. In both cases, however, the power to legitimate or to naturalize often lies outside the control of the affected individual and to that 
unlike similar nonsuspect characteristics such as intelligence and physical disability, they are said to "frequently [bear] no relation to ability to perform or contribute to society." 44 Third, they appear to have long been used by legislative majorities to discriminate against less powerful groups.45

These criteria, however, fail to provide consistently applicable standards for choosing which classifications are to be suspect. Laws forbidding consenting adult homosexuals from privately performing various sexual acts may easily be seen as suspect according to the Court's three criteria, yet the Court recently appears to have indicated that such laws would not be held unconstitutional. ${ }^{46}$

Another difficulty with the suspect classification approach is its tendency to encourage individuals to define themselves and others in terms of membership in certain classes or groups. This tendency is not surprising in light of the justification for the suspect classification approach, the special need for judicial protection of "discrete and insular minorities." 47 The Fourteenth Amendment, however, protects not only groups but also individuals. Why should membership in a particular group entitle one to additional judicial protection? The literal meaning of the equal protection clause and its legislative history indicate that it was designed to protect the rights of every individual. ${ }^{48}$ An unjustified denial of rights may be more obvious when it affects an identifiable group of persons, but it is also unconstitutional when it affects only individuals. ${ }^{49}$

extent illegitimacy and alienage may be said to be immutable. In In re Griffiths, $93 \mathrm{~S}$. Ct. 2851 (1973), and Sugarman v. Dougall, 93 S. Ct. 2842 (1973), however, the plaintiff aliens were apparently eligible to become citizens but chose not to do so. See note 37 supra.

44 Frontiero v. Richardson, 93 S. Ct. 1764, 1770 (1973) (plurality opinion).

45 Cf. id. at $1769-70$.

46 Paris Adult Theatre I v. Slaton, 93 S. Ct. 2628, 2641 n.15 (1973) (dictum). But cf. Note, The Legality of Homosexual Marriage, 82 YALE L.J. 573 (1973).

47 In United States v. Carolene Products, 304 U.S. 144 (1938), four Justices opined that "prejudice against discrete and insular minorities may be a special condition, which tends seriously to curtail the operation of those political processes ordinarily to be relied upon to protect minorities, and which may call for a correspondingly more searching judicial inquiry." Id. at $153 \mathrm{n.4}$ (citations omitted). One of the diffculties with this justification is that any minority group that is insufficiently influential in the state and national legislatures will be unprotected without searching judicial scrutiny of legislation. Since the Court has restricted the number of groups it will protect, all other similar minority groups, it may be argued, are denied equal protection. See generally authorities cited note 22 supra.

48 See generally C. Fairman, History of the Supreate Court of the United States, RECONSTRUCTION AND REUNION 1864-88, PART ONE, 1270-1300 (1971); J. TENBROEK, EQUAL UNDER LAw, 201-239 (1965); Graham, The Early Antislavery Backgrounds of the Fourteenth Amendment (pts. 1-2), 1950 Wis. L. REv. 479, 610.

49 From this point of view, the fundamental personal rights approach to equal pro- 
The strict scrutiny of the suspect classification approach, when combined with the minimal scrutiny of the reasonable relationship approach, has resulted in a rigid two-tier system in which the conclusion is almost automatic once the level of scrutiny is specified. ${ }^{50} \mathrm{~A}$ more flexible and realistic approach to judicial review would be preferable, provided that the alternative approach could avoid the dangers of ad hoc decision making. The primary objection to a more flexible approach is its similarity to the repudiated substantive due process approach taken by the pre-1937 Court.51

Judicial "balancing" in equal protection cases, however, does not differ in principle from the post-1937 Court's approaches to interpreting the equally vague provisions of the due process clauses. ${ }^{52}$ In both cases, the Court is required to give specific content to general provisions of the Constitution. Although the intent of the framers and constitutional history are relevant to such determinations, they are often not controlling. ${ }^{53}$ The Court is therefore required to balance the burdens imposed on individuals against the public good achieved by the laws in question. Under these circumstances, judicial opinions should articulate the various relevant factors and their respective weights. Only such a method can be said to be compatible with demands for candid and principled constitutional adjudication. ${ }^{54}$

An explicit and structured balancing approach is substantially equivalent to the pre-1937 Court's approach to defining the liberty protected by the due process clauses. Lochner $v$. New York ${ }^{55}$ and its progeny,

tection protects individuals as individuals, while the suspect classification approach protects individuals as members of identifiable classes. Although the latter approach is particularly appropriate for laws that discriminate against racially defined minorities, it is unnecessary to expand the list of suspect classifications to protect other groups because a fundamental personal rights approach could easily provide equal or greater judicial protection. See text and notes at notes 82-127 infra.

50 "Strict scrutiny" under the Court's fundamental personal rights approach often appears to be similarly defective. See, e.g., Harper v. Virginia Bd. of Elections, 383 U.S. 663, 670, 680 (1966) (Black \& Harlan, J.J., dissenting). See generally, Note, The Decline and Fall of the New Equal Protection: A Polemical Approach, 58 VA. L. Rev. 1489 (1972). But see text and notes at notes 88-115 infra.

51 See, e.g., Weber v. Aetna Cas. \& Sur. Co., 406 U.S. 164, 177 (1972) (Rehnquist, J., dissenting).

52 See note 38 supra. See generally Comment, Equal Protection in Transition: An Analysis and a Proposal, 41 FoRD L. REv. 605 (1973).

53 See generally Dworkin, The Jurisprudence of Richard Nixon, 18 N.Y. REv. of Books, May 5, 1972, at 27. For provocative defenses of the contrary position, see L. Hand, The Bur of Rights (C. Wyzanski ed. 1968) and Bork, Neutral Principles And Some First Amendment Problems, 47 IND. L. REv. 1 (1971).

54 See, e.g., A. Bickes, The Least Dangerous Branch (1962); Wechsler, supra note 34; Gunther, supra note 12; Gunther, In Search of Judicial Quality on a Changing Court: The Case of Justice Powell, 24 Stan. L. REv. 1001 (1972).

65198 U.S. 45 (1905). 
however, are almost instinctively believed to represent a thoroughly discredited approach to constitutional adjudication. ${ }^{56}$ The Court has strenuously attempted to avoid the impression that it is balancing its view of the legitimacy and worth of legislatively chosen ends against its view of the magnitude of the burdens imposed on affected individuals to achieve those ends.57 As an alternative to such explicit balancing, the Court appears to be developing a third approach to equal protection, an intermediate level of judicial scrutiny embodied in the "substantial relationship in fact" test.

\section{Substantial Relationship in Fact}

In a few recent equal protection cases, the Court has found legislation unconstitutional while purportedly applying the traditional reasonable relationship test. ${ }^{58}$ As a number of the Justices and commentators have argued, the Court's actual approach in these cases implies that a higher degree of judicial scrutiny is being applied than the minimal judicial scrutiny embodied in the reasonable relationship test. ${ }^{59}$

In Reed v. Reed, ${ }^{60}$ for example, the Court held that Idaho's probate statute was unconstitutional insofar as it required men to be preferred to otherwise equally qualified women as administrators of estates. Idaho's justification for the classification was twofold. First, in general men were thought to have more experience than women in business matters relevant to the administration of estates. Second, the costs of granting judicial hearings to those women who claimed to be more qualified outweighed the benefits of occasionally discovering a better administrator. Minimizing governmental expenditures is a legitimate end and preferring men to women because of their greater business experience bears a reasonable relationship to the goals of minimizing expenditures and of appointing qualified administrators. The Court nevertheless

56 See, e.g., Dean v. Gadsden Times Publishing Corp., 93 S. Gt. 2264 (1973) (per curiam summary reversal); Ely, The Wages of Crying Wolf: $A$ Comment on Roe v. Wade, 82 YALE L.J. 920, 935-49 (1973). But see R. Posner, Economic ANALYsis of LAw 266-72 (1973).

67 A few Justices have explicitly acknowledged and approved of the post-1937's Court's return to a substantive due process approach. Roe v. Wade, 410 U.S. 113, 167 (1973) (Stewart, J., concurring); see Griswold v. Connecticut, 381 U.S. 479, 499 (1965) (Harlan, J., concurring); cf. $i d$. at 502 (White, J., concurring).

68 United States Dept. of Agriculture v. Moreno, 93 S. Ct. 2821 (1973) (Fifth Amendment equal protection); James v. Strange, 407 U.S. 138 (1972); Jackson v. Indiana, 406 U.S. 715 (1972); Stanley v. Illinois, 405 U.S. 645 (1972); Humphrey v. Cady, 405 U.S. 504 (1972); Eisenstadt v. Baird, 405 U.S. 438 (1972); Reed v. Reed, 404 U.S. 71 (1971); see Gunther, supra note 12, at 18-20.

60 E.g., Frontiero v. Richardson, 93 S. Ct. 1764 (1973) (plurality opinion); Guther, supra note 12, at 24-37; see text and notes at notes 62-81 infra.

60404 U.S. 71 (1971). 
held that this kind of classification was "the very kind of arbitrary legislative choice forbidden by the Equal Protection clause."61

Four Justices later argued in Frontiero $v$. Richardson ${ }^{62}$ that since the traditional reasonable relationship test was not applied, Reed must have held that sex is a suspect classification. Alternatively, Reed might be viewed as evidence for what some lower federal courts have called the "substantial relationship in fact" approach to equal protection. ${ }^{63}$ Under this approach, the state would be required to prove that the distinction drawn between men and women in Reed was factually supported and that the nonrebuttable preference for men substantially reduced governmental expenditures. ${ }^{64}$ The probable outcome of such an approach would have been invalidation of the mandatory preference for men since Idaho apparently had little evidence in the record to support the distinction.

The substantial relationship in fact approach, by applying an intermediate level of judicial scrutiny, might permit a state law that creates a rebuttable presumption that men are better qualified to administer estates so long as the law allowed individual women to challenge that presumption in a judicial hearing prior to the appointment of an administrator. ${ }^{65}$ In Frontiero, however, eight of the Justices held that a nonrebuttable presumption that all married men in the uniformed services supported their wives, combined with a rebuttable presumption that married women did not support their husbands, was unconstitutional. Four of the Justices explicitly declared that sex was a suspect classification. ${ }^{68}$ The other four did not explain their concurrence in the result except insofar as their citation to Reed implies that Congress's differential treatment of men and women was unjustified. If sex is not suspect, rebuttable presumptions favoring men and disfavoring women or vice versa might be constitutional. If such presumptions would never or almost never be constitutional, then the position of the four concurring Justices in Frontiero would not differ from the positions of those Justices who declared sex to be suspect. ${ }^{67}$

61 Id. at 76.

6293 S. Ct. 1764 (1973) (plurality opinion).

63 See text and notes at notes 68-81 infra.

64 See Frontiero v. Richardson, 93 S. Ct. 1764, 1771-72 (1973) (plurality opinion); cf. Vlandis v. Kline, 93 S. Ct. 2230 (1973).

65 Cf. Stanley v. Illinois, 405 U.S. 645 (1972).

66 Frontiero v. Richardson, 93 S. Ct. 1764, 1771 (1973).

67 If sex is suspect or the proposed Twenty-seventh Amendment is ratified, rebuttable presumptions favoring men and disfavoring women or vice versa would be ipso facto unconstitutional unless such presumptions were justified by the equivalent of a necessary relationship to a compelling governmental interest. Cf. Brown et al., The Equal Rights Amendment: A Constitutional Basis for Equal Rights for Women, 80 YALE L.J. 871, 893- 
A more explicit attempt to define and apply a level of judicial scrutiny midway between the minimal and strict levels is found in several recent opinions by the United States Court of Appeals for the Second Circuit, ${ }^{68}$ of which Boraas v. Village of Belle Terre ${ }^{68}$ is the most interesting. In Boraas the court held that the village's zoning ordinance that limited occupancy of dwellings in one family districts to traditional families or to groups of not more than two unrelated persons was unconstitutional. After reviewing the reasonable relationship and suspect classification approaches to equal protection, the court said that "the Supreme Court appears to have moved . . . toward a more flexible and equitable approach. . . . Under this approach the test for application of the Equal Protection Clause is whether the legislative classification is in fact substantially related to the object of the statute."70

This "newer" approach thus purports to differ from the traditional reasonable relationship approach by refusing to hypothesize the existence of facts that would indicate that the challenged classification was reasonably related to legitimate governmental goals. According to the majority opinion, the newer approach does not require "a flexible standard based upon balancing of the importance of the respective conflicting governmental and private interests affected by the legislation under review."71

An examination of the majority's application of this approach, however, calls into serious question the accuracy of the above description. The court first disposed of the district court's reason for upholding the ordinance, namely, "the interest of the local community in the protection and maintenance of the prevailing traditional family pattern."72 Although other courts have said that this is a legitimate governmental goal, ${ }^{73}$ the Court of Appeals said that "such a goal fails to fall within the proper exercise of state police power. . . . Such social preferences

96 (1971). Three of the Justices in Frontiero acknowledged that they did not reach the question of whether sex is constitutionally suspect because the Twenty-seventh Amendment is still before the states for ratification. Id. at 1773. Since it now appears that the Amendment may not be ratified, it is likely that the Court will have to decide this question. Cf. Harper v. Board of Elections, 383 U.S. 663, 680 (1966) (Harlan, J., dissenting).

68 Aguayo v. City of New York, 473 F.2d 1090, 1108-10 (2d Cir. 1973); City of New York v. Richardson, 473 F.2d 928, 930-31 (2d Cir. 1973); Green v. Board of Educ., 473 F.2d 629, 632-37 (2d Cir. 1973).

60476 F.2d 806 (2d Cir. 1973), appeal filed, 42 U.S.L.W. (U.S. July 27, 1973) (No. 73-191).

$70 \mathrm{Id}$. at 814 (emphasis in original).

71 Id. at 815 n.8.

72 Id. at 815.

73 See, e.g., Reynolds v. United States, 98 U.S. 145 (1878); Tenants Union v. Morgan, 321 F. Supp. 908 (N.D. Cal. 1970); Baker v. Nelson, 291 Minn. 310, 191 N.W.2d 185 (1971). But see United States Dept. of Agriculture v. Moreno, 93 S. Ct. 2821 (1973). 
... while permissible in a private club, have no relevance to public health, safety or welfare."'74

The court's narrow holding, however, did not rest on the newly discovered illegitimacy of one of the primary goals of local land use regulation. For the sake of the argument, the court conceded that the "purpose" of the ordinance was legitimate, but held that "we fail to find a shred of rational support for the means used here to achieve that end."75

If the goal of the ordinance is to encourage the formation of traditional family units, prohibiting nontraditional housekeeping units of more than two persons from living in Belle Terre appears to be a rational means of doing so. With respect to its goal, it may be argued, the only defect of the ordinance is that it is underinclusive insofar as it permits a nontraditional housekeeping unit of two persons. Although this exception may impede Belle Terre's achievement of its goal, it is hardly a sufficient basis for finding the ordinance unconstitutional unless the strict scrutiny test is being applied.

After summarily dismissing the argument that the challenged classification did in fact bear a substantial relationship to its legitimate purpose, the court held that the evidentiary record and judicial notice did not supply a sufficient factual basis for finding a substantial relationship to other legitimate purposes, such as the control of population density, noise, automobile congestion, or rent levels.

As the dissenting opinion persuasively argues, the majority's approach to equal protection is equivalent to the strict scrutiny approach that is applied to suspect classifications. ${ }^{76}$ Although Belle Terre appears to have the opportunity to establish a sufficient factual basis for a judicial finding of a substantial relationship between its ordinance's classification and legitimate goals, this possibility is illusory in light of the court's requirement that only the least restrictive alternative means would have a substantial enough relationship. ${ }^{77}$ Since the court said that all of Belle Terre's legitimate goals could be achieved by other, less restrictive, means (such as restrictions on the number of bedrooms and automobiles per dwelling unit, nuisance laws, and rent controls), the court's decision, as its author later acknowledged, ${ }^{78}$ clearly requires the village to redraft its land use regulations. The possibility of new regulations passing the court's substantial relationship in fact test is,

74476 F.2d at 815 .

75 Id. at 816 .

$76 I d$. at 818 (Timbers, J., dissenting).

77 See 476 F.2d at 817; cf. id. at 824 (Timbers, J., dissenting).

78 Id. at 829 (reply to dissent from denial of rehearing en banc). 
however, open to question since the new test appears to be nothing more than a new name for the strict scrutiny test designed to avoid defining a new suspect classification or applying unenumerated fundamental personal rights.

"Newer" equal protection in the form of a principled and candid substantial relationship in fact approach cannot avoid judging the legitimacy and worth of legislatively chosen ends. ${ }^{79}$ As commentators have persuasively argued, whether the means chosen bear a substantial relationship to legislative ends depends on how the Court interprets the purpose of the legislation..$^{80}$ The opinions in Reed, Frontiero, and Eisenstadt ข. Baird ${ }^{81}$ indicate that under the new test the Court feels free to ignore several plausible legitimate ends to which the challenged law's classifications bear a substantial relationship. Thus newer equal protection, at least in its present form, appears to be an unsuccessful attempt to create a principled form of intermediate scrutiny.

The creation of a new test in order to justify more than minimal judicial scrutiny is, moreover, unnecessary. The Court, both prior to 1937 and, more importantly, afterward, may be seen as applying higher levels of judicial scrutiny to legislation infringing on unenumerated fundamental personal rights. ${ }^{82} \mathrm{~A}$ fundamental rights approach, although not without its own difficulties, need not twist facts and legislative goals in order to reach the desired judicial result and can provide a generally acceptable standard that would allow the Court to recognize explicitly that individuals' rights are restricted by legislation and to weigh the benefits to society from those restrictions against the burdens imposed. ${ }^{83}$

Perhaps most importantly, a fundamental personal rights approach is likely to be more acceptable than a suspect classification approach. The fundamental personal rights doctrine has a long and respected history in the United States and permits explicit balancing of governmental against individual interests. ${ }^{84}$ The greater acceptability of the

79 See 476 F.2d at 815 n.8: "[T] nature of the classification under attack, the rights adversely affected and the governmental interest in support of it." But cf. text at note 71 supra (quoting from the same footnote).

80 E.g., Brest, Palmer v. Thompson: An Approach to the Problem of Unconstitutional Legislative Motive, 1971 SUP. CT. REv. 95. Ely, Legislative and Administrative Motivation in Constitutional Law, 79 YALE L.J. 1205 (1970); Note, Legislative Purpose, Rationality and Equal Protection, 82 YALE L.J. 123 (1972).

81405 U.S. 438 (1972) (plurality opinion), discussed in Note, supra note 80, at 124-28.

82 See text and notes $85-115$ infra.

83 See text and notes at notes 105-127 infra.

84 See generally, Bertelsman, The Ninth Amendment and Due Process of Law-Toward a Viable Theory of Unenumerated Rights, 37 U. CIN. L. REv. 777 (1968); Carpenter, 
fundamental personal rights approach would encourage the Court to be more explicit about balancing and to articulate coherent standards to structure the weighing of interests in future cases.

\section{- II. The Court's Fundamental Personal Rights Approach} to Equal Protection

After the Court repudiated economic due process adjudication in 1937, it began to apply a fundamental personal rights approach to some equal protection cases. For example, the Court held in Skinner $v$. Oklahoma ${ }^{85}$ that Oklahoma's Habitual Criminal Sterilization Act was subject to strict judicial scrutiny because it involved "one of the basic civil rights of man," the right to procreate. ${ }^{86}$ In later cases the Court explicitly developed the doctrine that an unjustified burden on certain unenumerated fundamental personal rights was sufficient to find state and federal laws unconstitutional. ${ }^{87}$

As has been recognized both by members of the Court and by commentators, these cases are essentially similar in approach to pre-1937 substantive due process cases in that they weigh the legitimacy and worth of the ends chosen by the legislature against the burdens imposed on affected individuals' rights in order to achieve those ends. ${ }^{88}$ 'Two fundamental personal rights that typify this branch of the post-1937 Court's approach to the equal protection clause are the right to travel and the right to vote.

\section{A. The Right to Travel}

The right of United States citizens to travel throughout the United States was recognized and protected by the Court even before the ratification of the Fourteenth Amendment. In Crandall v. Nevada ${ }^{89}$ the Court held that the nature of the Union and United States citizenship prohibited Nevada from imposing a one-dollar tax on only those persons leaving the state by common carrier. The Court balanced the actual

Substantive Due Process at Issue: A Resume, 5 U.C.L.A.L. REv. 47 (1958); Kurland, supra note 27; Schaefer, The Fourteenth Amendment and Sanctity of the Person, 64 Nw. U.L. REv. 1 (1969); Comment, The Growth of Procedural Due Process into a New Substance: An Expanding Protection for Personal Liberty and a "Specialized Type of Property ... in Our Economic System," 66 Nw. U.L. REv. 502 (1971); authorities cited note 48 supra and note 116 infra.

85316 U.S. 535 (1942).

$86 \mathrm{Id}$. at 541.

87 Dunn v. Blumstein, 405 U.S. 330 (1972); Shapiro v. Thompson, 394 U.S. 618 (1969); Harman v. Forssenius, 380 U.S. 528 (1965).

88 See authorities cited note 38 supra; $c f$. authorities cited note 84 supra and note 116 infra.

8973 U.S. (6 Wall.) 35 (1867). 
and possible burdens on the individual's right to travel against the purpose of the legislation, the raising of revenue for the state. Since Nevada did not claim that the tax was a justified user charge for state-provided facilities that specifically benefited the traveler, the Court found the tax unconstitutional.90

The post-1937 Court continued to protect the right to travel and found both state and federal legislation to be unconstitutional infringements of that right. In Edwards $v$. California ${ }^{91}$ the Court held that a state statute imposing criminal penalties on those who brought indigent nonresidents into the state was unconstitutional. The goal of the statute was arguably legitimate. Due to severe droughts in the southwestern states, thousands of poor persons were migrating to California. The additional burdens these new residents imposed on California were severely aggravated by the Great Depression. The law attempted to limit these burdens. The Court balanced this justification against the burdens the statute imposed on the individual's right to migrate to and settle in any state in the Union and held that no state could "isolate itself from the difficulties common to all of them by restraining the transportation of persons and property across its borders." 92

It is important to note that although poor migrants are members of an identifiable group, that group was not held to be a "discrete and insular minority." ${ }^{33}$ Strict judicial scrutiny in Edwards was formally based on the commerce clause. Four concurring Justices maintained that the constitutional source of protection for the right to travel was the privileges and immunities clause of the Fourteenth Amendment. Although Edwards, therefore, is technically not an equal protection clause case, $^{94}$ a more recent right to travel case, Shapiro $v$. Thompson, ${ }^{85}$

80 In Evansville-Vanderburgh Airport Auth. Dist. v. Delta Airlines, 405 U.S. 707 (1972), the Court balanced the benefits achieved by a $\$ 1.00$ tax on all departing air travellers, i.e., use of a publicly built and operated airport, against the burden imposed and found the $\$ 1.00$ tax to be a reasonable approximation of the cost of conferring the benefit. The Court held that such a tax did not impose a "burden in the constitution sense" on the right to travel and was therefore constitutional. Id. at 714. For similar examples of balancing in a fundamental rights context, see text and notes at notes 91-115 infra.

91314 U.S. 160 (1941).

$92 \mathrm{Id}$. at 173.

93 For an argument that state discrimination against poor migrant farm workers is suspect, see Gallegos v. Glaser Crandell Co., 388 Mich. 654, 668, 202 N.W.2d 786, 791 (1972) (Kavanagh, J., concurring).

94 For a similar reluctance to invoke the equal protection clause or the right to travel, see Toomer v. Witsell, 344 U.S. 410 (1948), discussed at note 27 supra. Toomer adopted some of the views expressed in the concurring opinions in Edwards and found unconstitutional a law discriminating against out-of-state fishermen on the basis of the privileges and immunities clause of Article IV, section 2. Whatever specific clause may be invoked, the right to travel may be viewed as a "derivative" right based on the nature 
explicitly held that the right to travel is also protected by the equal protection clause.

In Shapiro the Court held that neither Congress nor the states could impose a one-year-in-the-state residency requirement for welfare benefits on migrants to the District of Columbia or the states. Shapiro extended the Constitution's protection of the right to travel by ruling that withholding welfare benefits from migrants for one year sufficiently burdened their right to travel to overcome the justifications offered for the regulation by Congress and the states.

What distinguishes Shapiro from cases where the Court did defer to Congress and the state legislatures is the presence of an unjustified burden on a fundamental personal right. ${ }^{96}$ Although Edwards and Shapiro may be read as cases protecting the poor, the primary rationale for these decisions, applicable to other cases not involving the poor, is the Court's protection of an unenumerated fundamental personal right. The class characteristics of those persons whose exercise of a fundamental right is burdened is irrelevant; the determining factor is whether the burden imposed on the individual is justified. ${ }^{97}$

In Dunn v. Blumstein ${ }^{98}$ the Court continued its explicit protection of the individual's right to travel by holding that Tennessee's one-yearin-the-state and three-month-in-the-county residence requirements for voting for United States Senators and Representatives and for state and local officers were unconstitutional. Although the decision might have been based solely on the denial of the fundamental right to vote, the Court emphasized that the right to travel was an independent basis for its holding. Given the burdens imposed on the exercise of two fundamental personal rights, the Court was not persuaded that the durational residence requirements were the least burdensome means to prevent fraud and avert voter ignorance. ${ }^{99}$

In Doe v. Bolton ${ }^{100}$ the Court again protected the fundamental

of the Union or as an "inherent" right based on the nature of American liberty. See Comment, The Right to Travel: Another Constitutional Standard for Local Land Use Regulations?, 39 U. CHr. L. REv. 612, 629-33 (1972). For the distinction between "derivative" and "inherent" rights, see Bork, supra note 53.

95394 U.S. 618 (1969).

96 See Weber v. Aetna Cas. \& Sur. Co., 406 U.S. 164, 173 (1972): “The essential inquiry . . . is, however, inevitably a dual one: What legitimate state interest does the classification promote? What fundamental personal rights might the classification endanger?"

97 See San Antonio Independent School Dist. v. Rodriguez, 93 S. Ct. 1278, 1295-97 (1973). See generally Comment, supra note 94.

98405 U.S. 330 (1972).

$99 \mathrm{Id}$. at $345-60$.

100410 U.S. 179 (1973). 
personal right to travel by holding that Georgia's law limiting abortions to bona fide residents of the state was unconstitutional. Although the requirement of bona fide residence promoted the state's interest in assuring adequate "post-procedure medical care for the aborted patient,"101 the Court apparently thought that the burden imposed on the right to enter a state outweighed the state's justifications for the -legislation.

\section{B. The Right to Vote}

Prior to 1937 the Court's protection of the right to vote was essentially limited to prohibiting racial discrimination under a narrow interpretation of the Fifteenth Amendment. ${ }^{102}$ In a few cases, however, the Court extended constitutional protection of the right to vote beyond the literal requirements of the Fifteenth Amendment. In the first White Primary Cases, ${ }^{103}$ for example, the Court held that the Fourteenth Amendment's equal protection clause prevented the states from denying Blacks the right to vote in primary elections.

After 1937 the Court extended its protection of the right to vote to prohibit the denial to Blacks of the right to vote in all primary and preprimary elections. ${ }^{104}$ These cases relied on the Fifteenth Amendment and focused on the question of whether sufficient "state action" was involved in the primary and preprimary elections; they may be read, however, as right to vote as well as racial discrimination cases.

Later cases establish that the Constitution's protection of the right to vote extends far beyond the specific provisions of the original Constitution and the Fourteenth, Fifteenth, Seventeenth, Nineteenth, Twentythird, Twenty-fourth and Twenty-sixth Amendments. In Dunn $v$. Blumstein, ${ }^{105}$ for example, the Court held that denying the right to vote for state and federal officers to new residents of the state was unconstitutional. Although Tennessee's restrictions on new residents helped to achieve the compelling goals of preventing fraud and voter ignorance, the Court explicitly balanced the public good achieved against the burden imposed and the possibility of less onerous but

101 Id. at 200.

102 See, e.g., Comment, The Right to Vote and Restrictions on Crossover Primaries, 40 U. CHI. L. REv. 636, 638-40 (1973); Comment, Durational Residence Requirements for Candidates, 40 U. CHI. L. REv. 357, 358-60 (1973).

103 Nixon v. Condon, 286 U.S. 73 (1932); Nixon v. Herndon, 273 U.S. 536 (1927).

104 Terry v. Adams, 345 U.S. 461 (1953); Smith v. Allwright, 321 U.S. 649 (1944).

105405 U.S. 330 (1972); cf. Carrington v. Rash, 380 U.S. 89 (1965) (denying the right to vote to new-resident servicemen unconstitutional). 
equally or more effective alternatives and held that the restrictions in question were insufficiently justified. ${ }^{106}$

Similarly, in Harper v. Virginia Board of Elections, ${ }^{107}$ the Court in effect balanced the burden imposed on the right to vote for state officers, a poll tax of $\$ 1.50$, against the state's justifications of dissuading the disinterested from voting and raising revenue, and concluded that even such a small burden on the right to vote was unconstitutional.

In Bullock v. Carter ${ }^{108}$ the Court explicitly balanced the burdens imposed on the right to vote and the right to be a candidate by various filing fees against the benefits attained, for example, more comprehensible ballots. The Court indicated that a reasonable filing fee would be constitutional. Should the Court specify what constitutes a reasonable fee, only a balancing approach that weighed the burdens imposed on fundamental personal rights against governmental justifications would explain the result. ${ }^{109}$

The Reapportionment Cases ${ }^{110}$ are also consistent with a fundamental rights analysis that emphasizes judicial balancing of burdens and benefits. Although some early cases have been read as requiring absolute equality in the weight of all votes cast and simple majority rule in all elections, ${ }^{111}$ later cases, such as Abate v. Mundt, ${ }^{112}$ Gordon v. Lance, ${ }^{113}$

$106 \mathrm{Id}$. at 345-60. Although the durational residency requirements at issue in Dunn impinged upon both the right to vote and the right to travel, the Court later held that the right to vote could be denied and the right to travel infringed by durational residence requirements (in the form of registration deadlines) of up to fifty days. Marston v. Lewis, 93 S. Ct. 1211 (1973) (per curiam); Burns Fortson, 93 S. Ct. 1209 (1973) (per curiam). In these cases the Court held that the burdens imposed on the exercise of fundamental personal rights were outweighed by the benefits attained by registration deadlines, e.g., the prevention of fraud at the polls. The Court acknowledged that " [f]ixing a constitutionally acceptable period is surely a matter of degree." $93 \mathrm{~S}$. Ct. at 1213 (quoting Dunn v. Blumstein, 405 U.S. 330,348 (1972)).

107383 U.S. 663 (1966).

108405 U.S. 134 (1972).

109 The Court recently agreed to review Lubin v. Panish, - Cal. 3d. -, - Cal. Rptr. -, - P.2d -, cert. granted, 93 S. Ct. 2152 (1973) (No. 71-6852), "in order to consider conflicts in holdings regarding the constitutionality of state filing fee statutes." Brown v. Chote, 93 S. Ct. 1732, 1736 n.5 (1973).

110 E.g., Kirkpatrick v. Preisler, 394 U.S. 526 (1969); Wells v. Rockefeller, 394 U.S. 542 (1969); Avery v. Midland County, 390 U.S. 474 (1968); Reynolds v. Sims, 377 U.S. 533 (1964); Wesberry v. Sanders, 376 U.S. 1 (1964).

111 See generally A. Bicked, The Supreme Court and the IdeA of Progress 151-81 (1970); Kurland, Foreword: "Equal in Origin and Equal in Title to the Legislative and Executive Branches of the Government," 78 HARv. L. REv. 143 (1964). But cf. Auerbach, The Reapportionment Cases: One Person, One Vote-One Vote, One Value, 1964 Sur. Cr. REv. 1.

112403 U.S. 182 (1971).

113403 U.S. 1 (1971). 
Mahan v. Howell, ${ }^{114}$ and Salyer Land Co. v. Tulare Water District, ${ }^{115}$ have indicated that the Court's decisions are not based on an "egalitarian" or "majoritarian" rationale but on a fundamental rights approach. This approach defines the right to vote and weighs the burdens imposed on it in light of practical differences between different governmental bodies and the states' justifications for deviations from exact equality and simple majority rule. Thus, the right to vote is not simply the right to an equal vote or to equal participation in elections, but more significantly is the right to cast a vote appropriately restricted on the basis of the nature and functions of the governmental body in question, the nature of the burdens imposed on voters, and the government's justifications for the restrictions.

\section{Two EXAmples of an Explicit Fundamental Personal Rights Approach}

One of the difficulties with the Court's present fundamental personal rights approach is its frequent failure to acknowledge explicitly that burdens on fundamental personal rights are balanced against the public good likely to be achieved by the legislation or regulation in question and to specify all the relevant burdens and benefits and their relative weights. 110 In two recent cases, moreover, the Court has attempted to avoid a fundamental personal rights analysis by substituting various

11493 S. Ct. 979 (1973). But cf. White v. Weiser, 93 S. Ct. 2438 (1973).

11593 S. Ct. 1224 (1973).

116 See generally authorities cited note 54 supra. It might be suggested that one of the reasons why the Court has avoided using a fundamental rights approach in all but a few cases is that the problem of defining which rights are to be considered "fundamental" would result in unprincipled and unstructured opinions. The fundamental rights approach has, however, a long history that could provide the necessary structure as the Court worked out the exact definition of rights to be protected and the weights to be given them. See, e.g., Corfield v. Croyell, 6 F. Cas. 546, 551-2 (No. 3,230) (C.C.E.D. Pa. 1823); authorities cited supra notes 48 and 84 ; cf. Brandeis and Warren, The Right to Privacy, 4 HARV. L. REv. 193 (1890). Justice Marshall dealt with the problem of definition in his dissent in Rodriguez:

The majority is, of course, correct when it suggests that the process of determining which interests are fundamental is a difficult one. But I do not think the problem is insurmountable. And I certainly do not accept the view that the process need necessarily degenerate into an unprincipled, subjective "picking-and-choosing" between various interests or that it must involve this Court in creating "substantive constitutional rights in the name of guaranteeing equal protection of the laws." Although not all fundamental interests are constitutionally guaranteed, the determination of which interests are fundamental should be firmly rooted in the text of the Constitution. The task in every case should be to determine the extent to which constitutionally guaranteed rights are dependent on interests not mentioned in the Constitution.

San Antonio Independent School Dist. v. Rodriguez, 93 S. Ct. 1278, 1332 (1978) (quoting from the majority opinion, id. at 1297). 
less desirable approaches. The following discussion will attempt to show that an explicit fundamental personal rights approach to these cases would be more principled and yet more flexible than the Court's approaches.

\section{A. San Antonio Independent School District $v$. Rodriguez ${ }^{117}$}

In Rodriguez the Court held that Texas's reliance on local property taxes to finance public schools was not unconstitutional. The threejudge federal district court below had held that Texas's financing system denied students in low property tax base communities equal protection of the laws. ${ }^{118}$ The Supreme Court reversed and held that Texas's local property tax system of school financing was rationally related to legitimate governmental goals. Strict scrutiny was not applied by the Court because property tax base differences among local communities were held not to be suspect and the right to education was apparently held not to be a fundamental personal right.

An alternative reading of Rodriguez, however, supports the view that the Court implicitly applied a fundamental personal rights approach. This reading would begin with the Court's emphasis on the plaintiffs' failure to prove that the differences in revenue received by Texas public schools had a causal connection with the quality of education provided. ${ }^{119}$ Second, the Court emphasized that even if the right to education were fundamental, there was no evidence in the record that the lowest quality level of education provided in Texas was below the level a fundamental right to education would require. ${ }^{120}$ Finally, the Court emphasized that "[e]very step leading to the establishment of the system Texas utilizes today ... . was implemented in an effort to extend public education and to improve its quality." 121 With these points in mind, the Court may be seen as holding that even if the right

11793 S. Ct. 1278 (1973).

118 Rodriguez v. San Antonio Independent School Dist., 337 F. Supp. 280 (W.D. Tex. 1971), rev'd, 93 S. Ct. 1278 (1973).

11093 S. Ct. at 1302-04 \& nn.86 \& 101. The Court emphasized that "one of the hottest sources of controversy concerns the extent to which there is a demonstrable correlation between educational expenditures and the quality of education-an assumed correlation underlying virtually every legal conclusion drawn by the District Court in this case." Id. at 1302 (citations omitted).

$12093 \mathrm{~S}$. Ct. at 1298-99. In discussing whether the right to education is an implicit fundamental right because citizens need a sufficient education to exercise their First Amendment right to freedom of speech and their fundamental right to vote, the Court said that "[e]ven if it were conceded that some identifiable quantum of education is a constitutionally protected prerequisite to the meaningful exercise of either right, we have no indication that the present levels of educational expenditure in Texas provide an education that falls short." Id. This statement implies that the right to a basic education need not include the right to an education equal in either quality or level.

$12193 \mathrm{~S}$. Ct. at 1300 (emphasis in original) (citations omitted). 
to education is fundamental, the plaintiffs had not proved that a burden was imposed on that right by the Texas financing system..$^{122}$

This alternative analysis of Rodriguez is a better approach to the crucial question in the case, namely, whether the level of public education provided by Texas was inadequate due to its system of local property tax financing. In answering this question the Court should be seen as having balanced the plaintiffs' evidence that Texas's educational financial system was inadequate against numerous governmental justifications for the system. The Court's opinion in Rodriguez would have been more persuasive if it had acknowledged and developed its implicit weighing of the various relevant rights, burdens, and justifications involved.

An explicit balancing approach in Rodriguez would take due account of the plaintiffs' claims by acknowledging the relative importance of public education in our country and of the defendant's claims by acknowledging the relative importance of a system of local property tax financing. The crucial element in the balance would be the effect of the latter on the former. In Rodriguez, given the evidence in the record, it would be sufficient to say that the plaintiffs had not proved that the financing system imposed a burden (let alone an unjustified burden) on their right to education. In future cases, perhaps Lau $v$. Nichols, ${ }^{123}$ for example, if plaintiffs do in fact prove that burdens were imposed, the Court would decide whether the government's justifications were sufficient to overcome the burdens imposed on individuals' fundamental rights.

\section{B. Vlandis v. Kline $e^{124}$}

In Vlandis the Court held that Connecticut could not conclusively presume that persons who applied to the state university from out-ofstate were not bona fide residents of Connecticut for tuition purposes during their attendance at the university. The Court held that Connecticut's irrebuttable presumption of nonresidence violated the due

122 The Court will have the opportunity next term to hold explicitly that the right to education is or is not fundamental. In Lau v. Nichols, 472 F.2d 909 (9th Cir.) (advance sheet) (opinion withdrawn by order of court), cert. granted, 93 S. Ct. 2786 (1973), the Court of Appeals held that San Francisco's failure to provide all non-English-speaking Chinese public school students with compensatory instruction in English language was constitutional. The Supreme Court might, however, find that a de facto racial classification renders San Francisco's failure "suspect," and thus Lau may not settle the question of whether the right to education is fundamental. Cf. Hawkins v. Town of Shaw, 437 F.2d 1286 (5th Cir. 1971), adhered to on rehearing en banc, 461 F.2d 1171 (1972).

123472 F.2d 909 (9th Cir.) (advance sheet) (opinion withdrawn by order of court), cert. granted, 93 S. Ct. 2786 (1973) (discussed in note 122 supra).

12493 S. Ct. 2230 (1973). 
process clause because it did not offer an individual the opportunity to prove at a hearing that he was in fact a bona fide resident.

The Court's reasoning in Vlandis is open to the serious objection that it would invalidate the thousands of laws and regulations that employ what the Court terms irrebuttable presumptions. ${ }^{125}$

From a fundamental personal rights point of view the crucial question in Vlandis was whether Connecticut's definition of the bona fide residency required for lower tuition at the state university unjustifiably impinged upon potential and actual students' right to travel among the several states. Had the Court approached the case in this manner, principled distinctions could be made between the "irrebuttable presumption" involved in Vlandis and those created by many other laws and regulations. Moreover, the Court, under this approach, would explicitly weigh the magnitude of the burden imposed on the rights in question, i.e., the pecuniary difference between in-state and out-of-state tuition, against Connecticut's justifications for imposing the burdens. ${ }^{126}$ From this point of view, arguably, a reasonable difference between in-state and out-of-state tuition would be permitted. Instead of adopting this straightforward approach, the Court appears to be attempting to achieve the same result by implying, in a footnote, that a one-year-inthe-state residence requirement for in-state tuition rates would not violate the due process clause. ${ }^{127}$ The Court's indirect approach to the crucial question in Vlandis appears to have few if any advantages over an explicit fundamental rights approach. More importantly, the indirect approach has the severe disadvantage of making principled application of the reasoning to future cases extremely difficult.

\section{Conclusion}

The reasonable relationship and suspect classification approaches to judicial review of legislative and administrative action were developed

125 The same objection may be raised against the Court's reasoning in the similar case of United States Dept. of Agriculture v. Murry, 93 S. Ct. 2832 (1973). The only principled holding of these cases consistent with their procedural due process rationales implies that all nonrebuttable legislative and administrative presumptions are unconstitutional absent extraordinary governmental justifications. $C f$. Fuentes v. Shevin, 407 U.S. 67 (1972); Comment, Power of Sale Foreclosure after Fuentes, 40 U. Chi. L. Rev. 206, 225-28 (1972).

Had the Court based its decisions on fundamental personal rights, more principled, yet more flexible holdings would have been possible. $C f$. United States Dept. of Agriculture v. Moreno, 93 S. Ct. 2821, 2828 (Douglas, J., concurring).

$128 \mathrm{See} 93 \mathrm{~S}$. C. at 2240 (White, J., concurring).

$12793 \mathrm{~S}$. Ct. at 2236-37 \& n.9. Justice White noted in his opinion concurring in the judgment that "I have difficulty distinguishing, on due process grounds, whether deemed procedural or substantive or whether put in terms of conclusive presumptions, between the Minnesota one-year requirement and the Connecticut law that, for tuition purposes, does not permit Connecticut residence to be acquired while attending Connecticut schools." Id . at 2238. 
in part as a reaction to the lack of principles and structure that was perceived as plaguing the earlier substantive due process approach. The reasonable relationship and suspect classification approaches, however, have evolved into a usually rigid two-tier system of judicial review that has forced the Court to distort law and facts in order to apply one or the other test, because the test applied usually determines the result. This approach to judicial review lacks principles and structure as much as the pre-1937 Court's substantive due process approach. The substantial relationship in fact approach that seems to be developing, although a valid attempt to create a more candid and principled approach to judicial review, appears to share many of the same failings that detract from the reasonable relationship and suspect classification approaches.

An explicit balancing based on fundamental personal rights could provide the basis for an approach to judicial review that would be more flexible than the present approaches and still be principled and structured. Such an approach would be subject to various uncertainties as the Court developed definitions of what rights were to be considered fundamental and to what extent they should be judicially protected. This development, however, would be able to draw on a well-established line of fundamental rights precedents and, once developed, would be likely to be both more acceptable to the public and more in accord with our basic constitutional and political tradition of respect for the rights of every individual. 